The Geneva Papers on Risk and Insurance, 20 (No. 74, January 1995) 84-100

\title{
Organization and Strategy in Insurance Empirical Research into the Sector in Spain
}

\author{
by Miguel Angel Martínez Martínez*
}

\begin{abstract}
In 1993 the insurance sector in Spain achieved a premiums volume of 18.7 billion dollars (4.29 percent of the Gross Domestic Product) and, even within the widespread economic crisis in the Spanish and European economic framework, with $7 \%$ of growth respecting 1992 due to the sector's considerable development potentials.

The most significant results gained in this study point towards major changes in the company culture of these institutions in Spain, expanding their image of confidence with a greater commitment from their organizations towards the client. These are strongly centralized organizations where the principal business unit is formed by the product branch.

The preferred strategies in these companies have been those resulting from a growth of their activities in local markets, with zero penetration abroad (apart from certain exceptions) and where the diversification that is planned for the final decade of the century will be based on expanding the business branches: life, medical, pension funds, etc. The most complex bodies in the sector place a fair amount of importance in diversification into financial products, assistance services and risk management.

The organizational structures of a divisional nature are predominant in bodies with greater complexity, while it is diversifying strategies that have conditioned company groups characterized by multibusiness, with strategies based on price having been the variable on which organizational structures with a functional nature are based.

In general, the main organizational criterion for companies is the branch much more than the geographical area. The strategies existing in the past characterized their present structures.

\section{Reference framework}

Strategy and Organization are two key factors for company competitiveness. Everyone has to identify its strategic potentials which it will find both in its actual position of dominance compared with its competitors and in environments that affect it.

* Professor at the University of Alcalá de Henares. General Manager of FUNDACION MAPFRE ESTUDIOS Madrid. The research work is the basis of the doctoral thesis by the author, who was directed by Dr. Santiago García Echevarría, professor at the University of Alcalá de Henares (Spain).
\end{abstract}


The global framework of a company management system of a strategic nature is that in which the management exploits the actual company values and culture, or those potentials that are external and internal to the institution.

Figure 1: Reference framework of strategic management

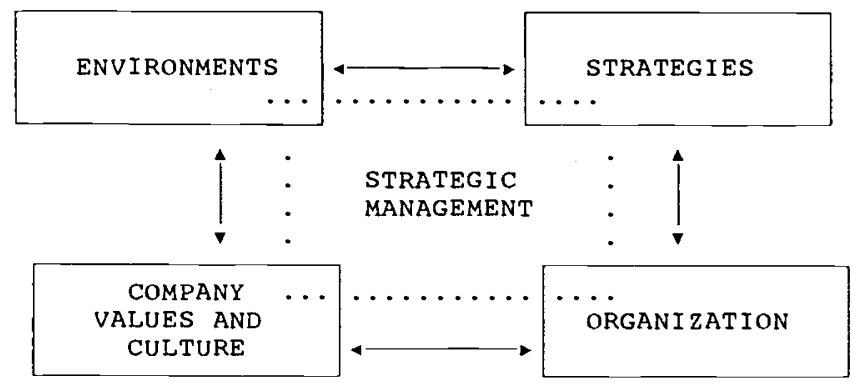

The four factors shown in figure 1 (Company culture, Organization, Environment and Strategies) are elements of the managerial system that require on-going and mutual adaptation, this continual adjustment being the most outstanding characteristic that differentiates companies, the one that gives them a greater or lesser degree of competitiveness and, consequently, the one that facilitates or hinders company success.

The relationship existing between Company Organization and Strategy has a particular interest and was studied some years ago, ${ }^{1}$ since from its possible causal links can be derived models of company consultation. The greatest difficulties when it comes to researching this relationship lie in seeking precise and defined characteristics for these factors which, being qualitative, have to be studied via their components.

\section{A research model}

The objective set regarded the conducting of an empirical analysis that would provide a response to questions on the nature and orientation that company organization and strategy were following in Spain, led to a research methodology with the stages summarized in fig. 2:

\section{Figure 2:}

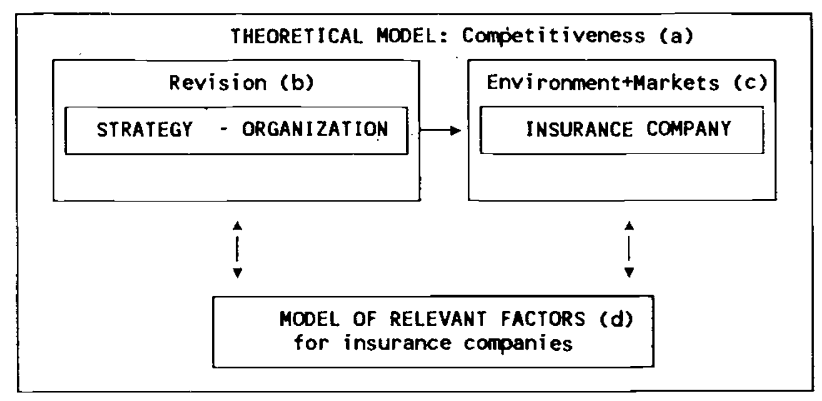

\footnotetext{
1 Chandler, A.: Strategy and Structure. MIT Press. Cambridge, Massachusetts, 1962. In a now classic study he maintains that each business strategy requires its own organizational structure.
} 
a: Introduction of a THEORETICAL-CONCEPTUAL MODEL that would help to focus on the central idea of competitiveness.

b: Revision of the DOCTRINAL CONTRIBUTIONS surrounding the concepts forming the subject of the work, as well as studies deriving from the company strategic-organizational relationship.

c: Specific study of the INSURANCE ENVIRONMENT in Spain (within the European Union), its juridical framework and markets, and also the differentiating characteristics of its companies and management styles.

$\mathrm{d}$ : Proposal for the Model of RELEVANT FACTORS "Strategy-Organisation", applied to insurance bodies.

Finally, this model will serve as a standard for the empirical analysis of the sector, clarifying the main variables of the survey that would be directed towards insurance companies in Spain.

\section{The theoretical dimensions}

The strategic-organizational problem was analysed following a theoretical model based on the analysis of the competitive capacities of the companies: their strategic potentials.

Different authors show how certain companies find their potentials through the analysis and utilization of their ENVIRONMENTS, both from a territorial perspective (for insurance companies in Spain this will basically be the European level) and from the perspective of the rules on each market.

Following the proposed model and, once the global competitiveness factors of the company have been introduced, two variables will be selected as the guiding capacities to be studied: STRATEGY and ORGANIZATION.

First, the concept of Strategy was studied in depth as a competitive orientation of the company management, based on the utilization of the environment and which is supported by the company culture.

Second, and with respect to Organization, its characteristics and components were studied, especially those which most affect its flexibility and capacity for change.

Finally, the research summarized here was focussed on seeking an operative dimension for classifying STRATEGY and ORGANIZATION via the study of their relevant factors.

\section{Studies on the strategic-organizational relationship}

The practice of company management in increasingly more complex environments has given a different meaning to the term strategy.

In the ' 60 s, at the time in which contingentialist organizational theories were being put forward, the term was used as a synonym for "Courses of action for attaining the results set down in planning" (Chandler, 1962); years later the formulation of strategy included the combination of opportunities and risks of the environment and the exploitation of company capacities (Hofer and Schendel, 1978). Today the term strategy is used in a wider sense, referring to the expected business behaviour within an adaptive model that includes company culture (Peters, 1982), as well as its relationship to and interaction with the Organization.

The study of company organizations becomes complicated when dealing with a multidimensional und qualitative concept, which in itself explains the fact that, surrounding it, 
Figure 3:

Theoretical Model: Competitive dimensions study STRATEGY-ORGANIZATION

of insurance companies in Spain

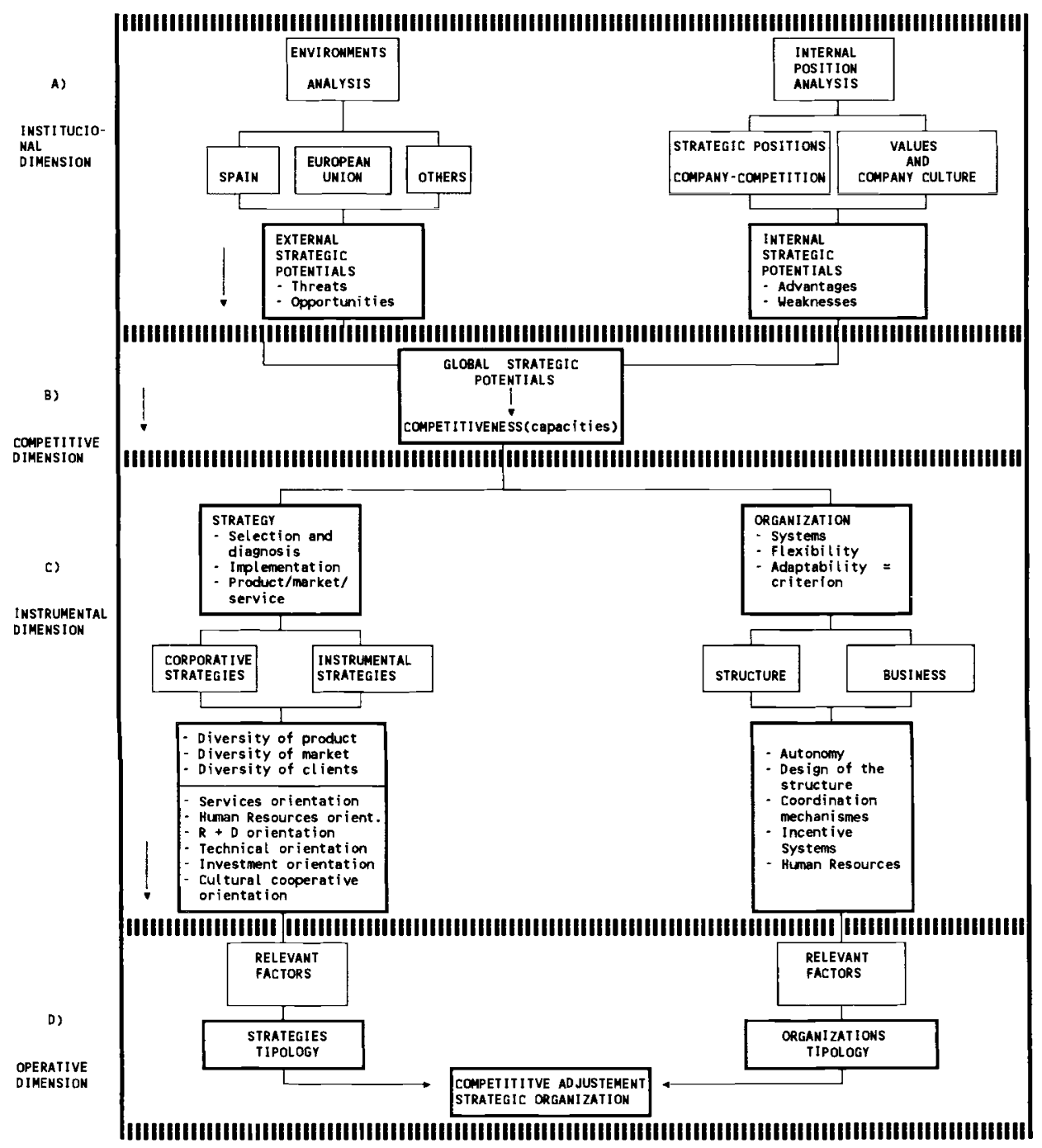


a doctrinal corpus has been developed centered on the search for valid models and structures for each company situation.

The organizational form as response or as platform for the various company strategies has been the element around which numerous researches have revolved. At the theoretical level we can quote Miles, R., 1978; Ulrich, H., 1978; Ansoff, 1990 and Mintzberg, 1991, and above all in the empirical studies we shall below refer briefly to the five groups of doctrinal contributions:

a. Studies of Alfred A. Chandler (1962)

In his work he analyses the behaviour followed by seventy major American companies undergoing sharp growth, and proposed the principle that the companies sequentially adapt their organizational structures to the adopted strategies. The orientation towards diversification will appear related to multidivisional forms.

\section{b. Extensions to Chandler's thesis}

Via the programmes followed in the Harvard Business School, L. Wrigley (1970), G. Pooley-Díaz (1972), D. Channon (1973), A. Thanheiser (1972), R. Pavan (1972) and B. R. Scott $(1973)^{2}$ studied the same relationship in other companies in the US, France, England, Germany, Italy and the European Community. The results are of a similar nature though with a certain delay in the introduction of complex organizational forms among European companies which, in the 70 s, found themselves in a more protectionist Europe than that of today.

J. R. Galbraith (1978) ${ }^{3}$ proposed various strategic dimensions when it comes to relating strategy and organization: he analysed products, geographical areas and degree of relationship in company processes, arriving at a model of company consultation.

c. Relationships with the environment and the degree of internationality

The growth of American multinational companies was the pretext for the well-known research conducted by J. Stopford and L. Wells in 1972 through the analysis of their strategies on the progressive internationalization and how this is linked to increasingly complex organizational forms, including parent company structures. ${ }^{4}$

Other studies (D. Miller, 1984) ${ }^{5}$ relate to strategies with the prevailing environment and finally with organizational structures, finding a close correlation between bureaucratic organizational forms and stable environments.

\section{d. Strategy-Organization and economic results}

Suitably adapted, strategy and organization again appear as key factors in organizations, this time searching for correlation with company results, especially with the economic performance (R. Rumeltt, 1974); D. Channon (1977) studied English service companies, including insurance companies, again supporting divisional models; R. E. White

2 Scott, B. R.: "The industrial state: Old Myths and New Realities". Harvard Business Review, 51. 1973 (pp. 133-148).

${ }^{3}$ Galbraith, J. R. and Nathanson, D.A.: "Strategy Implementation. The role of structure and process". West Pub. Co.: St. Paul, Minn, USA, 1978. 1985.

${ }^{4}$ Leontiades, J. C.: "Multinational Corporate Strategy. Meath and Company", Lexington, Mass.,

5 Miller, D.: "Configurations of strategy and structure: Towards a Synthesis". Strategic Management Journal, vol. 7, 1986. 
(1981) and G. Chandrasekaran (1981) analysed strategies and the degree of concentration of markets; and finally J. H. Horovitz $(1982)^{6}$ even compared strategy, management and managerial practices, correlating the greatest company success with the degree of decentralization.

\section{e. Permanent databases}

The PIMS programme ("Profit Impact of Market Strategies") was initiated in 1972 in the US with the aim of determining the strategic dimensions that affected the profitability and growth of companies. In a systematic manner the programme processes company results, market conditions and environments with a database of more than 4,000 business units in America and Europe.

The system has served as a support for sustaining such strategic principles as the relationship existing between profitability and quality or profitability and market share, etc., and currently continues to be a platform for numerous researchers. ${ }^{7}$

Another example that can be quoted is that of the OASIS database, started up by HAY Consultants in 1984 for identifying the effect of organizational variables on company strategic success; the criteria used in the studies are similar to the systems of financial audits.

\section{Insurance institution in Spain}

Forming part of the world of financial services from the managerial point of view, insurance companies have particular characteristics that affect their organizations and which we can summarize in these four points:

1. The probabilistic process enveloping the establishment of reserves and the necessary solvency of the companies has forced controlling authorities in each country towards highly detailed regulations with regard to their establishment and subsequent rendering of services.

In Spain these companies operate principally under the juridical form of Joint Stock Company and Mutual Company.

2. Since they deal with intangible goods, the "selling of security" has to be founded on quality services, both when it comes to a policy being taken out and when it comes to a claim, even stimulating the prevention of personal and business risks.

3. The figure of "intermediation" (insurance agents or brokers) determines the business, through direct sale or the use of new distribution channels, such as credit cards or even sales in Commercial and Savings Banks, are being more frequent.

4. On account of both the size and the scope of services in supranational markets, the process of internationalization through concentration, mergers and buying-selling operations on companies is becoming increasingly common in insurance.

\section{Insurance activity and the single market}

At the start of the '90s insurance in the European Union represented 23 percent of world insurance, behind the USA ( 44 percent) and Japan ( 25 percent). The current insurance

\footnotetext{
${ }^{6}$ Horovitz, J. H. and Thiétart, R.A.: "Strategy, management design and firms performance", Strategic Management Journal, Vol. 3, 1982.

${ }^{7}$ Buzzell, R. P. and Gale, B. J.: "The PIMS Principles. Linking Strategy to Performance". The Free Press, New York, 1987.
} 
offer is characterized by company concentration, European regulations on which have followed the direction of banking, though more slowly.

Community authorities have been searching to harmonize prudential regulations in respective countries, as well as their mutual recognition, in a lengthy process towards the single market with objectives such as:

- Eliminating restrictions and discriminations among European companies.

- Common authorization systems for the introduction of economic activity.

- Deregulation of the exercise of insurance distribution and services in different countries in the Union.

European regulations have been focused on numerous directives whose essential core is based on three "generations" of rules related to damage insurance and life insurance which, as can be seen in the figure, have accelerated their development seeking to eliminate any restriction that goes against the spirit of Maastricht.

\section{Figure 4: Community Directives INSURANCE MARKET}

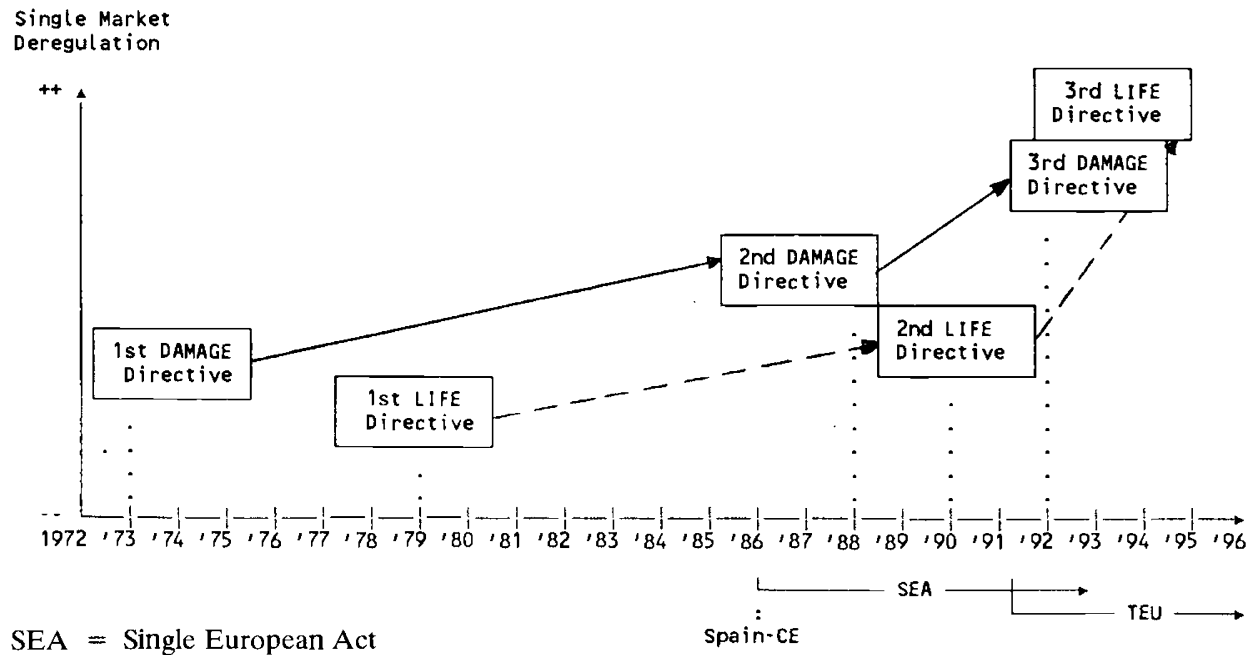

TEU $=$ Treaty of European Union

\section{Insurance Market}

The profitability of many big European insurance and reinsurance companies is falling, basically due to an excess of capacity ${ }^{8}$ (estimated at 30 percent), as well as to a change in strategy in insurance companies towards greater specialization, with much lower cost structures organized by products and clientele.

The Spanish insurance industry is undergoing a slow and, at the moment, insufficient process of concentration, going from more than 600 companies in 1981 to somewhat fewer

${ }^{8}$ Muth, M.: "Cambios estructurales en el sector asegurador europeo" (Structural changes in the European insurance sector), Harvard Deusto Business Review, No. 57, 1993 (pp. 78-87). 
than 400 in 1993, with the mutualist phenomenon losing importance due primarily to its rigidity and incapacity to follow the rate of growth imposed on the market.

In 1992, the top hundred companies in Spain represented 85 percent of premiums underwritten. In the context of economic crisis, the Spanish insurance market has had high growth, but at an increasingly lower proportion (23.8 percent in 1991, 16.6 percent in 1992 and 7 percent in 1993), reaching 18,7 billion dollars, which represents 4.29 percent of the GDP in that year (fig. 5).

Figure 5:

Total premiums / GDP\%

$\%$

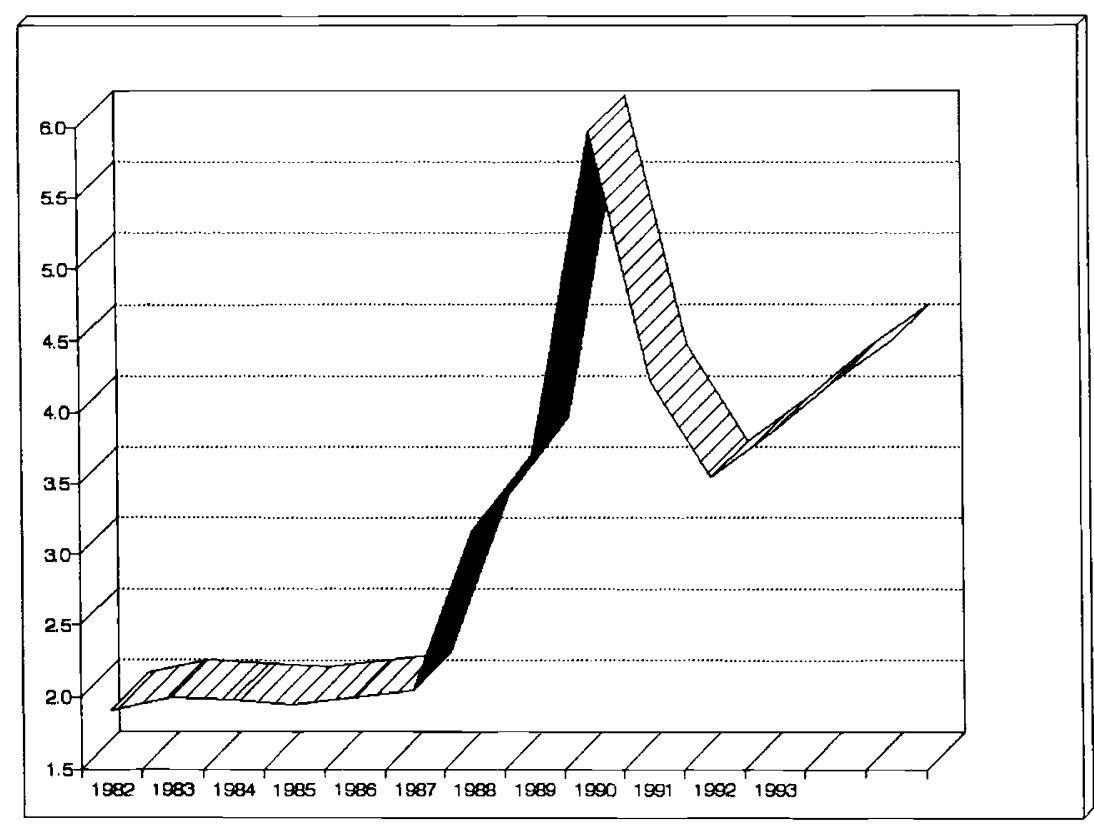

Source: UNESPA

Premiums / GDP

From the branch, we would remark the relative importance of Life Insurance and Pensions which, along with Medical Assistance, attained 39.2 percent of the market in 1992 with annual growths above the average for insurance in the last ten years (fig. 6).

The Motor Sector has maintained its share with close to 33 percent of the total premiums underwritten in Spain and, at the present moment, is suffering a considerable crisis of profitability due to its high administration costs.

The business structure that is today conditioning companies is moving towards segmentation in Personal Insurance ( 80 percent) and Company Insurance, with more integrating approaches in the supply of services. 
Figure 6:

Importance of the major branches

(Evolution over the decade)
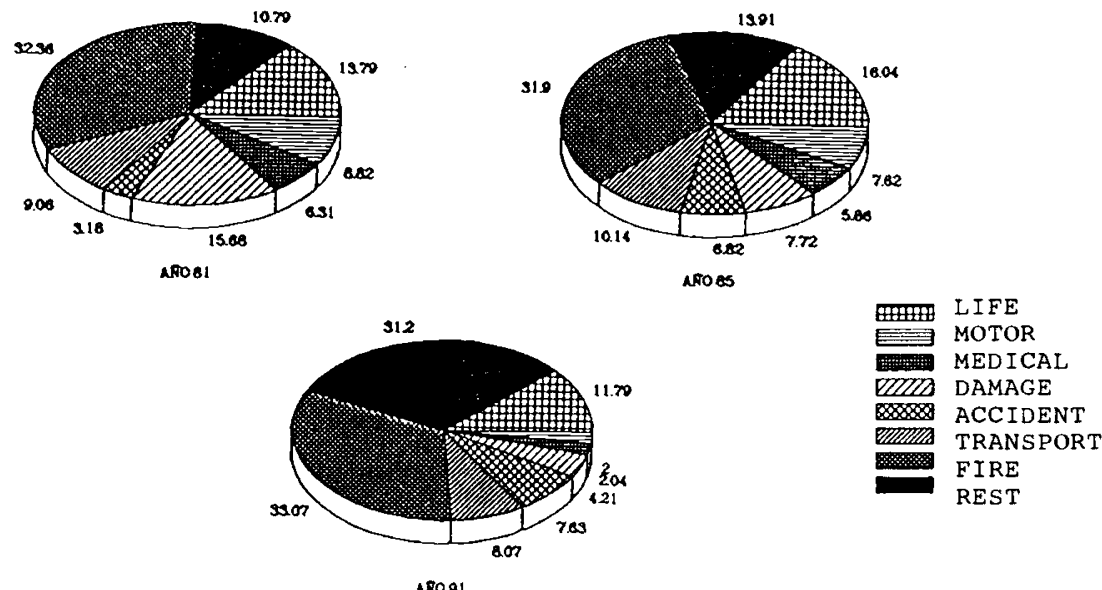

Source : UNESPA

IMPORTANCE

The further points characterize the insurance offer in Spain:

- The growth shown in the multinational sector: This is estimated at 42 percent of the market in 1993.

- The massive presence of credit institutions in the sector is notable, though not always with integrating strategies in their offer, except in the case of life insurance and, particularly, the EUROSEGUROS company from the BBV Group (Banco Bilbao-Vizcaya).

According to data from the UNESPA Employers' Association, the most important insurers are grouped into holdings headed in 1993, the Spanish group of companies MAPFRE, with 8,5 percent of the market, followed by Banco Central Hispano (and Generali) with 7,3 percent and of Banco Bilbao Vizcaya Holding with 4,0 percent.

The formation of new groups of companies is being conditioned by the economic crisis in Spain and the need to adapt company strategies to a new European insurance market, with clients that are more demanding with regard to the services that are provided and consequently less loyal to an exclusive brand.

\section{Proposal for a typological model of analysis of strategy and organization}

The stated characteristics that affect the insurance market decisively orientated the typological model used for defining its strategy and its organization.

This model of variables constituted the axis of the research via surveys that were focused on exploring each of its components. 
The model used in the study is shown in figure 7:

Model of components: Strategy-organization

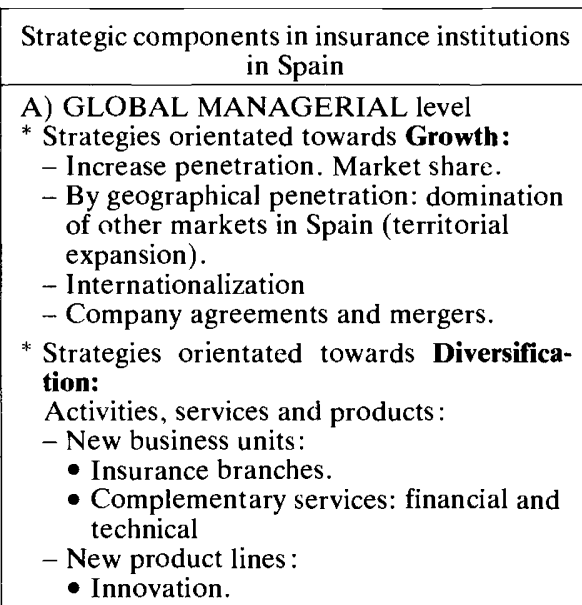

Strategies orientated toward Competitiveness: Improvement in the competitive position, Strengths and weaknesses.

- Cost reduction: productivity in internal and external expenses.

- Advantegeous premiums for the client.

- Differences in quality and benefits; contracting, attention to claims, services, etc.

- Speed of response.

B) FUNCTIONAL level

* Strategies orientated towards the client

- Risk selection

- Selection of market segments

* Strategies orientated towards marketing

- Products, prices

- Commercial and distribution network agents

- Image

* Strategies orientated towards productivity

- Data Processing

- Administration

* Strategies orientated towards service

- Customer care

- Quick claims response

* Strategies orientated towards solvency

- Technical and financial

* Strategies orientated towards the organization of the human resources

- Territorial presence

- Professional development

- Services "at a distance"

\footnotetext{
${ }^{9}$ Homogeneous product lines.
}

Organization components in insurance institutions in Spain

A) Diversity of business

\section{MODEL OF KEY ORGANIZATIONAL FACTORS IN INSURANCE COMPANIES IN SPAIN}

\section{A) DIVERSITY OF BUSINESS \\ - According to each geographical environment \\ - According to insurance branch ${ }^{9}$ \\ - According to complementary services}

B) COMPANY FORM AND SIZE

- Juridical form

- Ownership

- Employees

- Turnover

C) INSTRUMENTS OF INTEGRATION AND COORDINATION

- Planning

- Management by objectives

- Committees

- Other coordination systems

D) DECENTRALIZATION

- Degree of centralization

(decentralization)

- Type of centralized decisions

- Concentration of the personnel structures

E) ORGANIZATIONAL FORMS

(at corporate level)

- Functional

- Divisional (Business Unit)

- Divisional (Geographical Area)

- Matrix

- Holding 
The specific strategies of the insurance business, whose "intensive capital" is based primarily on human resources and is backed up by computing, were other criteria used when it came to selecting each specific variable included in the MODEL of ANALYSIS of relevant COMPONENTS for the Strategy and Organization of the Insurance Companies.

\section{Empirical study}

In the last four months of 1992 the fieldwork was conducted out on a survey sent to the Chairman or Executive Management of 360 insurance companies in Spain, the survey being introduced as a study of 217 variables being researched and on which their opinion was sought. The consultation was spread over the period 1980-1991 and over the immediate future, 1992-2000, and also included company expectations regarding a crucial period for the Spanish economy starting from the Single European Act.

The manager marked each variable considered between a minimum value (1) and a maximum (5). Answers with a mark greater than 4 (considerable) are reproduced in the following tables.

The responses covered 42 groups of companies, representing approximately 25 percent of the Spanish sector; 21 percent of companies having more than 1000 employees, 11 percent between 500 and 1000 employees and the remaining 68 percent with fewer than 500 employees.

The research conducted a segmented descriptive analysis, discovering the components that were the main conditioners of organization and strategy. A multivariant analysis was later conducted in order to determine the typological groups of bodies with common strategies and organizations and, finally, the correlation of these with their opposite variables was studied, searching for the causality relationship between organization and strategy.

\section{Significant conclusion}

- The managerial systems of insurance companies in Spain, characterized up to 1991 by their values founded on the confidence of the client, are rapidly changing towards quality, the client and the results being the factors that will orientate their future company culture (fig. 8) as revealed by the most consistent values according to the importance granted by the respondents.

Figure 8:

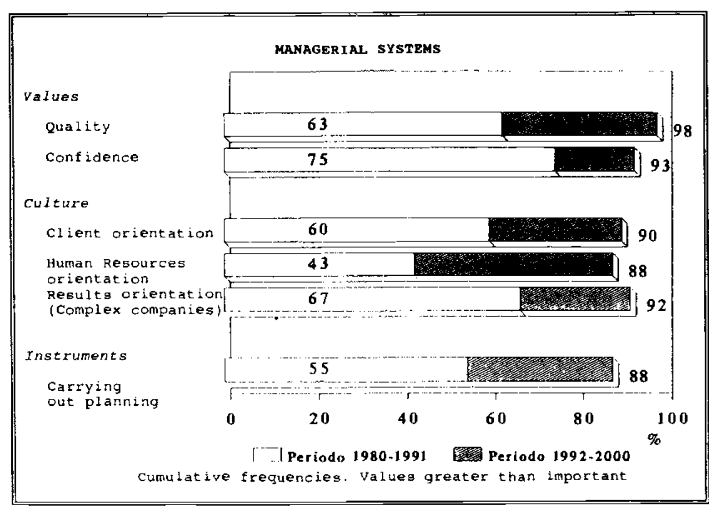


- international environments have almost no importance for Spanish companies when it comes to configuring their growth. The greatest opportunities that insurance companies in Spain see for themselves lie in our market and, above all, in Life and Pension Funds.

- In the future, company organizations will value their specialized branch approach, determining the divisional organizational form as being the most adapted to that need. (fig. 9).

Figure 9:

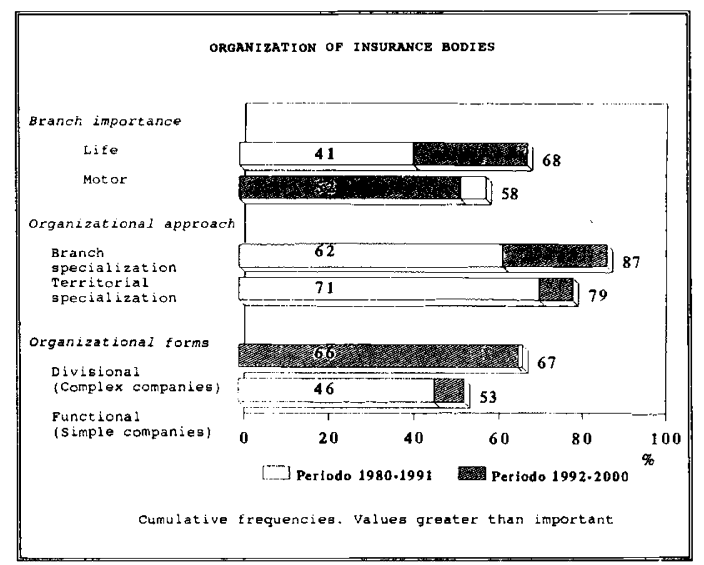

- Relevant global Strategies in the decade: Quality and growth in Spain. In the case of functional strategies, client attention in the event of a claim stands out as the key for the majority of bodies (fig. 10).

Figure 10:

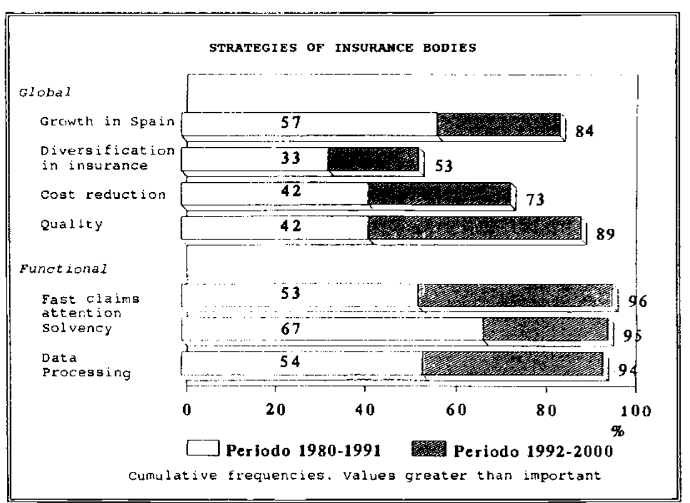


- With respect to the grouping of companies into different typologies with characteristic organizations, the cluster analysis revealed two groups of 18 and 21 cases respectively. Fig. 11 shows the mean of the responses for the variables surveyed $(1=$ Not at all important ... 5 = Very important).

Figure 11:

Organization and strategy in insurance

Organizational groups. Significant variables

$1980-1990$

$1991-2000$
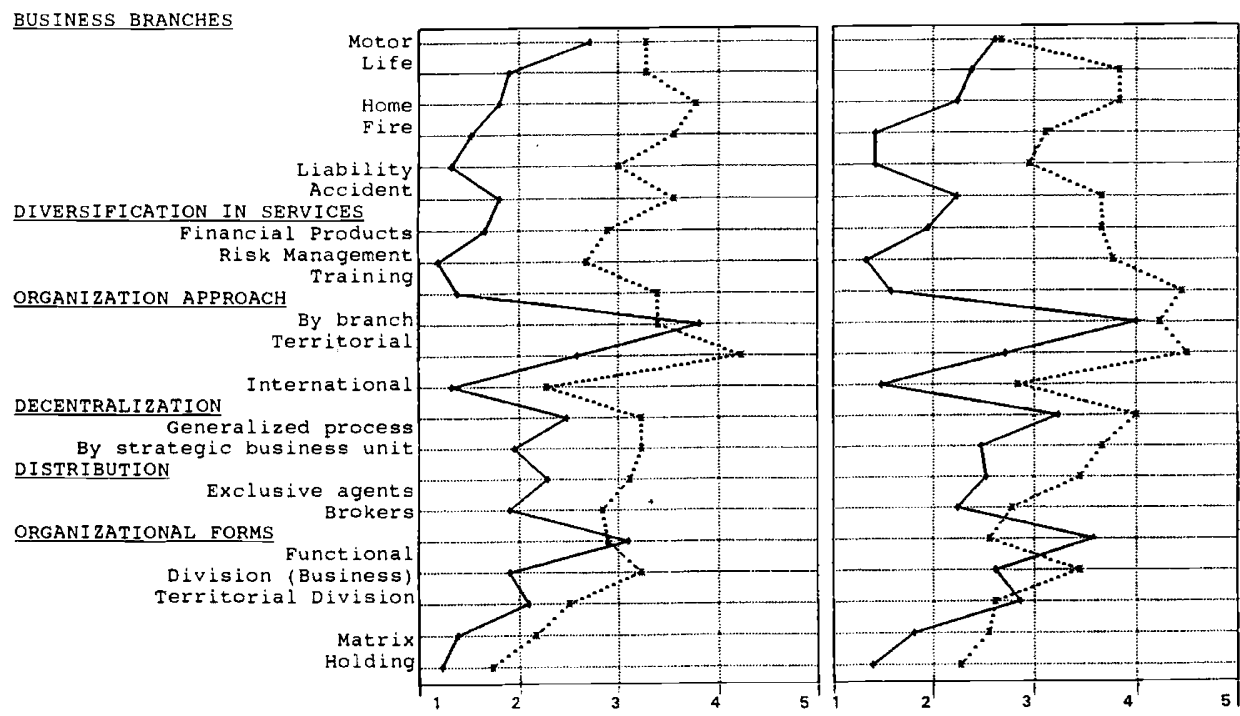

$n_{1}=18 \quad n_{2}=21$

Grupo 1: :-.....

Grupo 2:-

The characteristics of both groups in Spain were:

\section{Group 1}

- Complex companies (more than 500 employees) with a high proportion of multinationals (73 percent).

- Multiple business offer.

- Hybrid organizational form. Relevant importance of the branch.

Denomination: MULTIBUSINESS.

Group 2

- Simple companies (less than 500 employees).

- Concentrated into few branches.

- Functional organizational form. Denomination: FUNCTIONAL. 
With respect to the strategic typologies the cluster analysis revealed two groups of 28 and 11 cases respectively. See fig. 12 .

Figure 12:

Organization and strategy in insurance

Strategy groups. Significant variables

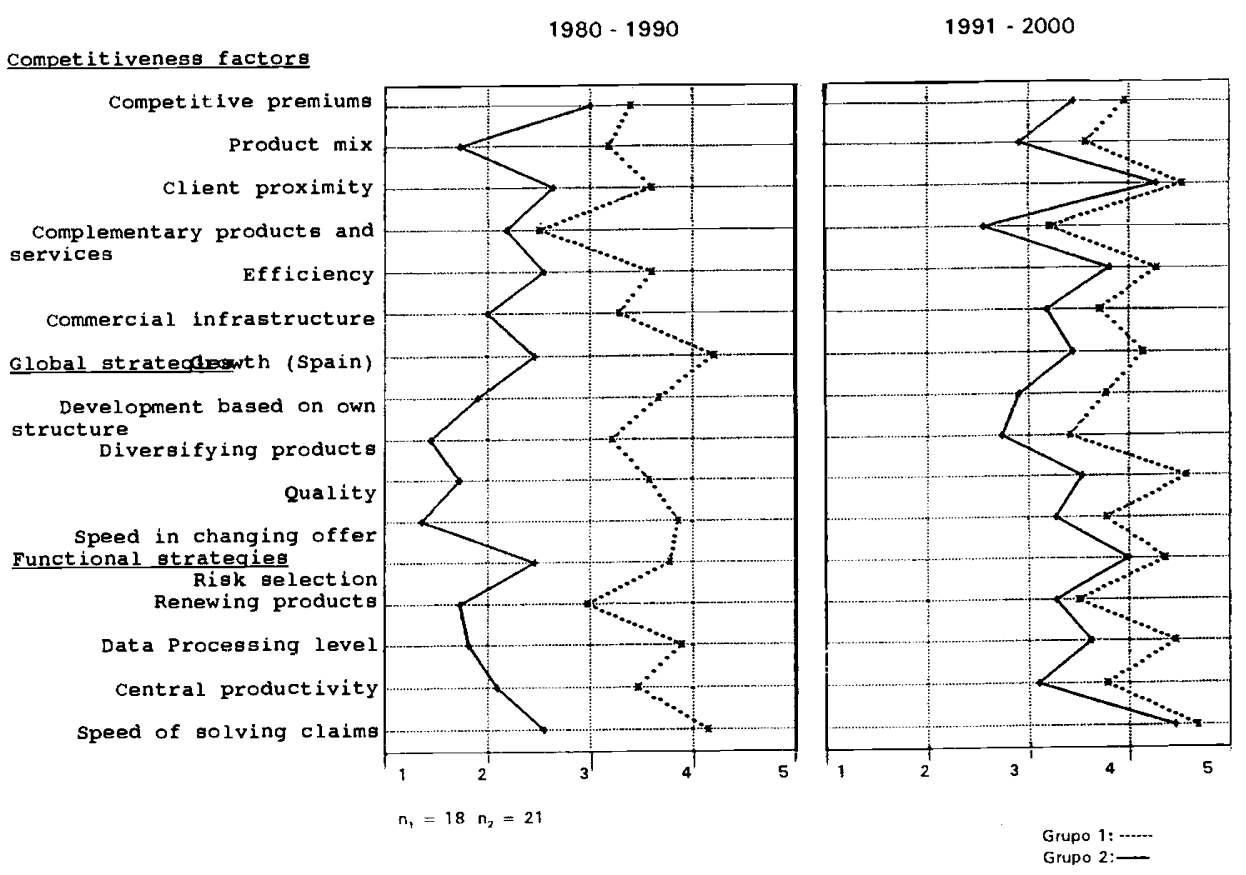

The characteristics were :

\section{Group 1}

- Operate in Motor, Life, General and other Insurance.

- They search for competitive advantage in the product mix.

- The search for strategies of proximity to the client.

Denomination: Oriented towards DIVERSIFICATION.

\section{Group 2}

- Simple bodies. Mutual companies dominating.

- Concentrated in Motor (82 percent) and/or General Insurance.

- Strategies based on competitive premiums.

Denomination: Orientated towards PRICES-SPECIALIZATION. 
The final section of the research conducted among the insurance companies included a statistical analysis ("log lineal regression") crossing the organizational and the strategic characteristics with the aim of verifying whether any congruence existed in the use of both components in managerial systems.

Is company organization configured as a response that boosts strategies in insurance companies...? Are the selected strategies designed from the point of view of the organizational structures?

- For the period 1980-1991, the multibusiness organizational group was significantly related with responses given regarding diversifying approach strategies, as well as the functional group being significantly related to competitive price strategies, a non-biunivocal relationship. It can therefore be said that the strategies existing in the past were those that characterize current organizational groups.

- For the period 1992-2000, the organizational groups that managers expect will characterize the companies do not have a firm relationship to the expected strategies. There is a certain confusion or divorce between the organizational form of the next decade and the strategies.

Solely the group characterized by diversification strategies are related to organizational forms decentralized into Business Units.

We could end this summary of the study by stating that the insurance companies surveyed, who represent a substantial part of the market, have found their organizational adaptation "ex post" to growth orientations in the various insurance branches via organizations of relatively low complexity adapted to the size of the Spanish market, perhaps at a first stage of their future evolution.

The internationalization of the markets and, for many companies, the fact that their decision centres lie outside Spain will accelerate the process - already begun - of reducing costs and the search for greater specialization in administration.

On the other hand, the integral attention surroundig the client, as well as computing, will lead to pressure towards organizations with flatter structures. ${ }^{10}$ In their turn, companies that already have more flexible structures will be allowed faster strategic adaptations: this is gathered in the study as being the needs of the Management System of Companies for the next decade.

\footnotetext{
${ }^{10}$ Fieten, R.: "Nuevas forms de Organización Empresarial a través del Lean Management" (New forms of Company Organization via Lean Management) BIFOA, University of Cologne. Seminar, University of Alcalá de Henares, 1993.
} 


\section{REFERENCES}

ALVAREZ JIMENEZ, C.: Gestión y Organización de entidades Aseguradoras. VI Seminario Internacional de Gerencia de Riesgos en empresas de seguros. Fundación Mapfre Estudios. Miami, 1993.

ANSOFF, H. I.: Strategic Management, Wiley, New York, 1979.

ANSOFF, H.I.: Corporate Strategy. McGraw Hill. New York, 1965.

BUZZELL, R.P. y GALE, B.J.: The PIMS Principles. Linking Strategy to Performance. The Free Press. New York, 1987.

CASTElo, J. y GUARDiola, A.: Diccionario MAPFRE de Seguros, $3^{a}$ ed. Ed. MAPFRE. Madrid, 1992.

CUADRAS, C. M.: "Métodos de análisis multivariante". 2e ed. Ed. PPU. Barcelona, 1991.

CHANDLER, A.: Strategy and Structure. MIT Press. Cambridge, Massachusetts, 1962.

DONALDSON, L.: In defence of organization theory. Cambridge University Press. Cambridge (UK), 1985.

FARNY, D.: "Insurance". Handbook of German Business Management. C.E. Poeschel Verlag: Springer Verlag, Berlin (etc.) 1990, p. 1167-1177.

FIETEN, R.: "Nuevas Formas de Organización empresarial a través del Lean Management" BIFOA, Universidad de Colonia. Seminario Universidad de Alcalá de Henares, 1993.

GALBRAITH, J.R. and NATHANSON, D. A.: Strategy Implementation. The role of structure and process. West Pub. Co.; St. Paul, Minn., USA, 1978.

GARCIA ECHEVARRIA, $S$.: El reto empresarial español: la empresa española y su competitividad. Ed. Díaz de Santos. Madrid, 1989.

HAX, A.C. and MAJLUF N. S.: Strategic Management. Prentice Hall Intl. Englewood Cliffs. N. J., 1984.

HOROVITZ, J.H. and THIÉTART, R. A.: "Strategy, management design and firms performance", Strategic Management Journal. Vol. 3, 1982.

ICEA y SRI International: Oportunidades estratégicas para la industria española de seguros. Informe 520, Asociación ICEA. Madrid, 1992.

LEONTIADES, J.C.: Multinational Corporate Strategy. Heath and Company. Lexington, Mass., 1985.

MARTINEZ MARTINEZ, M. A.: "Organización y Estrategia en la Empresa". Tesis doctoral presentada en la Universidad de Alcalá de Henares, Septiembre 1993.

MENGUZZATO, M. y RENAU, J.J.: La Dirección Estratégica de la Empresa. Ariel, Barcelona, 1991.

MILLER, D.: "Configurations of strategy and structure: Towards a Synthesis". Strategic Management Journal, Vol. 7, 1986.

MINTZBERG, H.: "Cómo modelar la estrategia". Harvard-Deusto Business Review, 2 tr. 1988.

MUTH, M.: "Cambios estructurales en el sector asegurador europeo". Harvard-Deusto Business Review, № 57, 1993, págs. 78 a 87.

NADL.ER, D. y TUSHMAN, M.: Strategic Organization Design. Scott, Foresman Co. Glenview, Illinois, 1988. Ed. by E. Grochla.

PORTER, M.E.: Estrategia Competitiva. CECSA. Madrid, 1984. 
PORTER, M.E.: Ventaja Competitiva. CECSA. Madrid, 1985.

PÜMPIN, C. y GARCIA ECHEVARRIA, S.: Management Estratégico. ESIC. Madrid, 1986.

PÜMPIN, C. y GARCIA ECHEVARRIA, S.: Cultura Empresarial. Díaz de Santos. Madrid, 1988.

PÜMPIN, C. y GARCIA ECHEVARRIA, S.: Estrategia Empresarial. Díaz de Santos. Madrid, 1993.

SCOTT, B.R.: "The industrial state: Old Myths and new Realities". Harvard Business Review, 51, 1973 , pp. 133-148.

THIETART, R. A.: La Stratégie d'entreprise. 2nd ed. McGraw Hill. Paris, 1991. 